\title{
Oxytetracycline hydrochloride activity in honey bee larvae (Apis mellifera) following medication with various doses
}

\author{
Ben Alexander MCKEE ${ }^{\mathrm{a} *}$, Russell David GOODMAN ${ }^{\mathrm{b}}$, Christian SAYWELL $^{\mathrm{c}}$, \\ Graham HEPWORTH ${ }^{\mathrm{d}}$

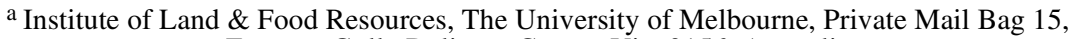 \\ Ferntree Gully Delivery Centre, Vic, 3156, Australia \\ b Department of Natural Resources \& Environment, Institute for Horticultural Development, Private Mail Bag 15, \\ Ferntree Gully Delivery Centre, Vic, 3156, Australia \\ ${ }^{c}$ Previously Department of Natural Resources \& Environment, State Chemistry Laboratory, \\ Corner Sneydes \& South Roads, Werribee, Vic, 3030, Australia \\ ${ }^{\mathrm{d}}$ Statistical Consulting Centre, Department of Mathematics and Statistics, The University of Melbourne, \\ Vic, 3010, Australia
}

(Received 11 December 2001; revised and accepted 29 October 2002)

\begin{abstract}
Four replicated experiments were conducted to determine the concentration of oxytetracycline hydrochloride (OTC) in honey bee (Apis mellifera) larvae following application of the antibiotic to honey bee colonies. In the first experiment, the mean OTC concentration was significantly greater in whole larvae than in larval guts sampled from hives on the day immediately following treatment. In two further experiments, $0.3 \mathrm{~g}, 0.5 \mathrm{~g}$ and $1.0 \mathrm{~g}$ active OTC in caster sugar was administered to single- and double-storey colonies. The mean OTC concentration was above the minimum inhibitory concentration of OTC to Melissococcus pluton for 2 to 6 days post-treatment, depending upon the dose. The daily rate of change of concentration of OTC in larvae sampled from treated colonies ranged from 0.423 to 0.672 . In a fourth experiment, application of $0.3 \mathrm{~g}$ and $0.5 \mathrm{~g}$ OTC in distilled water gave equal to or higher OTC levels in larvae on the first two days post-treatment when compared to the same doses applied in caster sugar.
\end{abstract}

oxytetracycline hydrochloride / antibiotic / honey bee / European foulbrood / Australia

\section{INTRODUCTION}

European foulbrood (EFB) is a disease of honey bee larvae (Apis mellifera L.) caused by the bacterium, Melissococcus pluton (Bailey \& Collins 1983) (Bailey, 1957). EFB occurs primarily in spring when numbers of M. pluton reach their peak. The disease can cause extensive losses of honey bee brood, honey production, and in severe cases death of the honey bee colony (Goodman et al., 1994).
The efficacy of the antibiotic, oxytetracycline hydrochloride (OTC) for control of EFB has been widely demonstrated by Katznelson et al. (1952), Lehnert and Shimanuki (1980) and Hornitzky et al. (1988). OTC is a bacteriostatic antibiotic that inhibits the multiplication of M. pluton. It is used in many countries and may be administered to hives in powdered sugar, sugar syrup or extender patties (Gilliam and Argauer, 1981).

\footnotetext{
* Correspondence and reprints

E-mail: ben.mckee@nre.vic.gov.au
} 
In Australia, commercial OTC products available for control of EFB stipulate application of $1 \mathrm{~g}$ active OTC to double-storey colonies (about 15 combs covered with bees) and $0.5 \mathrm{~g}$ to single-storey colonies $(8 \mathrm{combs}$ covered with bees). As there is a potential for the occurrence of OTC residues in honey (Lehnert and Shimanuki, 1981; Matsuka and Nakamura, 1990; Goodman et al., 1994), some Australian apiarists have reduced the dose of OTC they apply to their hives.

Hornitzky et al. (1988) treated 2-storey hives with either $1 \mathrm{~g}$ or $0.5 \mathrm{~g}$ active OTC and found that the period of detectable OTC in larvae ranged from 1 to 9 days following medication. In addition, the peak concentration of OTC in larvae sampled from all hives was above the minimum inhibitory concentration (MIC) of OTC for M. pluton, which they determined to be $3.8 \mu \mathrm{g} / \mathrm{mL}$. Later, Hornitzky and Smith (1999), conducted OTC sensitivity assays using a shorter incubation time than in the previous study on $104 \mathrm{M}$. pluton isolates sourced from four Australian States and determined the MIC for all isolates to be $1-2 \mu \mathrm{g} / \mathrm{mL}$.

The experiments described in this paper were conducted to determine if reduced doses of OTC (lower than $1 \mathrm{~g}$ active) applied to different sized hives and colonies would deliver sufficient antibiotic to honey bee larvae to meet or exceed the upper level of the MIC of OTC for M. pluton $(2 \mu \mathrm{g} / \mathrm{mL})$ established by Hornitzky and Smith (1999). The first experiment was a small study designed to determine if samples to be collected for antibiotic assays should consist of whole honey bee larvae or guts dissected from larvae.

\section{MATERIALS AND METHODS}

All experiments were conducted at Knoxfield, Victoria. Pre-treatment samples of at least 20 larvae were taken from all colonies used in these experiments and were analysed to confirm freedom from OTC contamination. Soluble broadspectrum OTC powder (100 g/kg OTC active) (Mavlab, Australia) was used in all experiments, with correction applied for the inert ingredients. The effect of OTC treatments on the honey bee colonies, plus unusual weather affecting honey bee foraging and possible clean-up of OTC treatments in the hives, was recorded.

\subsection{Experiment 1. Concentration of OTC in whole larvae and larval guts}

\subsubsection{Selection and treatment of colonies}

Two populous, 8-frame double-storey honey bee colonies, each with a single box broodnest, and similar numbers of adult bees, brood area and honey were selected. The colonies had access to an extremely light nectar flow. On 25 January 2000, $1 \mathrm{~g}$ active OTC in caster sugar made up to $100 \mathrm{~g}$ of mixture was sprinkled between and on the top bars of the broodnest frames beneath the queen excluder, according to Australian OTC directions for use.

\subsubsection{Sampling techniques and treatments}

Larvae, aged approximately 4-5 days, were sampled from the middle two combs in each hive on day 1,3 and 6 post treatment. Each sample comprised ten pairs of larvae, each of which was identical in size and situated in adjacent cells of a brood comb. Five such samples were taken from each hive on each day, resulting in 300 pairs of larvae altogether. Immediately after sampling, one larva from each pair was set aside, and the other had its entire gut dissected. This resulted in three types of larval material or "treatments": (i) whole larva; (ii) entire gut dissected from second larva; (iii) remainder of second larva. Dissections were conducted by the same person using the method of Dade (1962). For each treatment, the larval material from the ten pairs within each sample was pooled, and the OTC concentration determined on the pooled material.

\subsubsection{Statistical analysis of data}

The mean OTC concentrations for each treatment were compared using analysis of variance (ANOVA) with 'not detectable' coded as 0 . For the day 1 readings, a logarithmic transformation was applied to account for the positive skewness in the data. The day 3 readings were not very skewed, and no transformation was necessary. No analysis was performed on the day 6 readings, as most were 'not detectable'. To measure the association between the OTC concentrations for the three types of larval material within a pair of larvae, correlation coefficients were calculated, and scatterplots examined. All analyses from this experiment, and from the other experiments described in this paper, were performed using the statistical package Genstat for Windows (Lawes Agricultural Trust, IACR-Rothamsted). 
Table I. Oxytetracycline treatment, number of combs of brood and adult bees for each treatment group for Experiments 2 and 3.

\begin{tabular}{cccc}
\hline \multicolumn{2}{c}{ Treatment } & \multicolumn{2}{c}{ Number of combs of brood and bees, and hive size } \\
\hline $\begin{array}{c}\text { OTC } \\
(\mathrm{g} \text { active })\end{array}$ & $\begin{array}{c}\text { Caster sugar } \\
(\mathrm{g})\end{array}$ & $\begin{array}{c}6 \text { combs of brood } \\
8 \text { combs of bees } \\
(\text { single storey) }\end{array}$ & $\begin{array}{c}6 \text { combs of brood } \\
16 \text { combs of bees } \\
\text { (two storey) }\end{array}$ \\
\hline 0.3 & 33.3 & 5 colonies $\$$ & 5 colonies \\
0.5 & 50 & 5 colonies & 5 colonies \\
1.0 & 100 & 5 colonies & 5 colonies \\
\hline
\end{tabular}

$\dagger$ In Experiment 3, number of combs of bees ranged from 14 to 16 .

$\$$ In Experiment 3, there were 4 colonies per treatment group.

\subsection{Experiment 2. Concentration of OTC in larvae following summer application of the antibiotic in caster sugar}

\subsubsection{Preparation of colonies}

Thirty hives of bees with no previous antibiotic treatment were randomly allocated to one of 6 treatment groups (Tab. I) using a row-column design of 3 rows of 10 hives. The hives of each treatment group and the honey bee colonies they contained were manipulated to ensure similar numbers of adult bees, brood and honey according to the parameters of the group (Tab. I). A very light nectar flow was in progress during the experiment.

\subsubsection{Treatment of colonies with OTC}

OTC was applied to the hives on 15 February 2000, according to the doses listed in Table I and method of application detailed in Experiment 1.

\subsubsection{Sampling of larvae}

Post-treatment samples were collected from all hives daily for 8 days commencing 24 hours after treatment. On days 9 and 10, samples were taken only from hives treated with $1 \mathrm{~g}$ OTC. Some exceptions applied to these arrangements: on day 1 , samples were not collected from 3 hives ( $1 \mathrm{~g}$ single storey, $0.5 \mathrm{~g}$ and $1.0 \mathrm{~g}$ double storey hives) because medication was observed in open cells and larvae may have been externally contaminated with OTC; on days 4 and 7 , only 50 larvae from two combs were collected from all hives due to extreme weather conditions considered likely to adversely affect the colonies; one single storey hive treated with $1 \mathrm{~g}$ active OTC was withdrawn from the trial because the brood died immediately after treatment. Data from this experiment were combined with data from Experiment 3 for statistical analysis.

\subsection{Experiment 3. Concentration of OTC in larvae following spring application of the antibiotic in caster sugar}

\subsubsection{Preparation and treatment of colonies}

Procedures and treatments were the same as those used in Experiment 2 except that there were only four replications per treatment group (Tab. I). This experiment was essentially a repetition of Experiment 2, except that it was conducted during spring when beekeepers would be expected to treat hives with OTC. Treatment of hives occurred on 30 September 2000; little if any nectar was available to the bees on that day.

\subsubsection{Sampling of larvae}

Due to extreme inclement weather on the first day after treatment, half of the 2-storey hives treated with $0.3 \mathrm{~g}$ or $0.5 \mathrm{~g}$ OTC and all hives treated with $1 \mathrm{~g}$ OTC were not sampled. One single storey hive treated with $1 \mathrm{~g}$ OTC was withdrawn from the trial because larvae were not available; sampling from another hive in this treatment group did not occur on days 2 or 4 due to lack of suitably aged larvae and included only 25 larvae on day 5 . As a result of deteriorating weather on day 7 , only 50 larvae were sampled from hives treated with $0.3 \mathrm{~g}$ or $0.5 \mathrm{~g}$ OTC and none were sampled from hives treated with $1 \mathrm{~g}$ OTC. On days 10 and 11 , only hives treated with $1 \mathrm{~g}$ OTC were sampled.

\subsubsection{Statistical analysis of data}

Because the procedures and treatments were the same for Experiments 2 and 3, the data were combined for statistical analysis. However, the effects of the two experiments were not ignored, but accounted for in each model fitted, and a treatment 
group by experiment interaction term included where appropriate. A logarithmic transformation was applied to OTC concentrations, because (i) plots of residuals against fitted values indicated that it stabilised the variance, and (ii) it produced relationships between OTC concentration and time, which were more linear. Results from days 1 to 6 only were analysed; from day 7 onwards, there were too many zero readings for comparisons between treatment groups to be of any consequence.

For each of days 1 to 6 , the means for each treatment group were compared using ANOVA. A least significant difference (1.s.d.) at $P=0.05$ was calculated for comparing any pair of means. For presentation purposes, the means were backtransformed to the natural scale, and this converted the 1.s.d. into a least significant ratio (1.s.r.). For example, an 1.s.r. of 1.6 implies that one mean must be at least 1.6 times larger than another mean in order to be significantly different at $P<0.05$.

Scatterplots of OTC concentration vs time (days since treatment) for each treatment group indicated an approximately exponential decrease in OTC. A linear regression of the logarithm of OTC concentration vs time was therefore fitted for each hive in the experiment. The fitted slope in the regression, back-transformed, estimates the rate of change of OTC concentration per day; a rate larger than 1 represents an increase, and a rate smaller than 1 a decrease. The intercept in the regression estimates the OTC concentration at day 0 , immediately following treatment and colony uptake of OTC. ANOVAs were used to compare the mean slopes and intercepts for the six treatment groups. An l.s.r. at $P=0.05$ was calculated for paired comparisons.

\subsection{Experiment 4. Concentration of OTC in larvae following spring application of the antibiotic in water}

This experiment was conducted in late spring during the honey bee colony build-up period. A very light nectar flow was available to the bees. Ten double-storey hives were standardised to contain 6 combs of brood, 15-16 combs of adult bees and similar quantities of honey. The hives were randomly allocated to either $0.3 \mathrm{~g}$ or $0.5 \mathrm{~g}$ OTC dissolved in $200 \mathrm{~mL}$ of distilled water, using a randomised block design. The concentration of sugar in each treatment, resulting from the carrier contained in the OTC product, was calculated. Treatments were applied to hives on 20 November 2000 , by pouring the medication between and on the top bars of the broodnest frames beneath the queen excluder. Hives were elevated at the front to ensure the liquid did not flow out the entrances. Post-treatment samples were collected from each hive daily for 9 days immediately after treatment.

\section{Statistical analysis}

The mean OTC concentrations in larvae for the $0.3 \mathrm{~g}$ and $0.5 \mathrm{~g}$ treatments were compared using ANOVA, for days 1, 2 and 3 (by day 4, all except two hives had no detectable OTC).

A linear regression of the logarithm of OTC concentration vs. days since treatment was fitted for each hive, for days 1,2 and 3. ANOVAs were used to compare the mean slopes and intercepts for the treatments.

\subsection{Larval sampling method}

Larvae were selected from a minimum of two brood combs and ranged in age from those recently hatched to those about to be capped. Larvae were removed from comb cells using tweezers. After collection of each sample of larvae all tweezers were thoroughly cleaned, flamed, washed in distilled water and dried to remove any residual OTC and larval material to prevent crosscontamination of the next sample. Samples were then placed in a $-18{ }^{\circ} \mathrm{C}$ freezer. In Experiments 2, 3 and 4, post-treatment samples consisted of 75 larvae, except where noted later in this paper.

\subsection{Analysis of larvae for OTC}

All samples obtained in Experiment 1 were analysed by high performance liquid chromatography (HPLC). The concentrations of OTC in larvae obtained in Experiments 2, 3 and 4 were lower than those of Experiment 1. Consequently, a combination of HPLC and microbial inhibition tests (MIT) were used in Experiments 2, 3 and 4 because MIT provided more accurate analytical results than HPLC when concentrations of OTC were lower than $2 \mathrm{mg} / \mathrm{kg}$ (data not shown). This was primarily a result of the sample consistency.

Samples were firstly prepared for MIT by homogenising the larvae of each individual sample and placing a $1.0 \mathrm{~g} \pm 0.05 \mathrm{~g}$ aliquot in a $15 \mathrm{~mL}$ centrifuge with MilliQ water to make a total volume of $4 \mathrm{~mL}$. This was then blended using a probe blender and centrifuged at $4000 \mathrm{rpm}$ and $4{ }^{\circ} \mathrm{C}$ for 10 minutes. A $13 \mathrm{~mm}$ antibiotic disc was dipped into the liquid and placed on a Bacillus cereus disc diffusion assay plate (spore suspension supplied by Difco Laboratories) and incubated overnight at $37^{\circ} \mathrm{C}$. B. cereus plates were prepared by dissolving $6.4 \mathrm{~g}$ of antibiotic medium \#2 in $250 \mathrm{~mL}$ of MilliQ water, which was then autoclaved for 15 minutes and held in a water bath at $55^{\circ} \mathrm{C}$ for at least 30 minutes. After adjustment of $\mathrm{pH}$ to $5.6 \pm 0.05$ using $1 \mathrm{M} \mathrm{HCl}, 0.1 \mathrm{~mL}$ of $B$. cereus was added to the media, which was then stirred and poured into sterile petri dishes. 
Relationship between oxytetracycline and zone of inhibition of Bacillus cereus

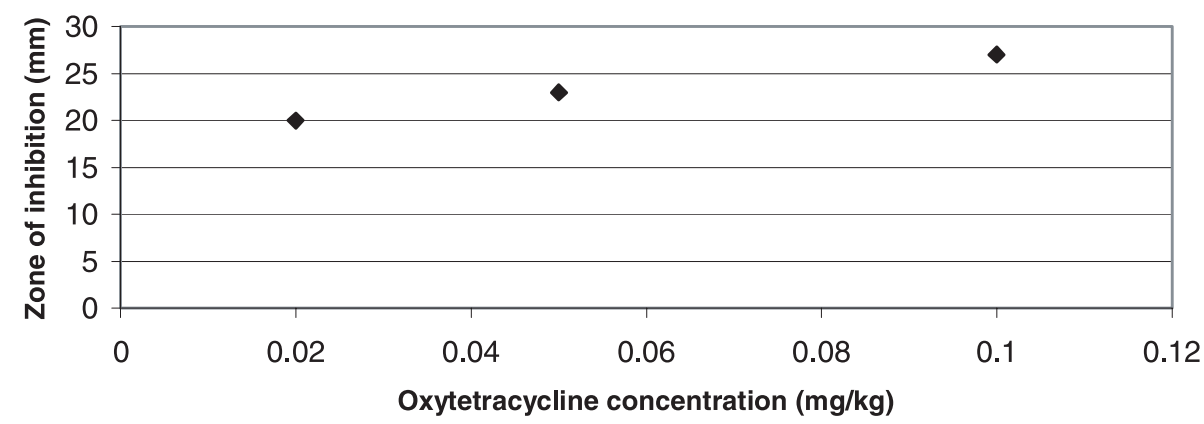

Figure 1. Relationship between oxytetracycline concentration and the zone of inhibition of Baccilus cereus.

Table II. Mean concentration of OTC $(\mathrm{mg} / \mathrm{kg})$ in whole larvae, larval guts and larvae with gut removed on day 1,3 and 6 following hive medication of two hives.

\begin{tabular}{lccc}
\hline Treatment & Day 1† & Day 3 & Day 6 \\
\hline Whole larvae & $98.4 \mathrm{a} \ddagger$ & $7.1 \mathrm{a}$ & 0 \\
Larval guts & $42.9 \mathrm{~b}$ & $5.1 \mathrm{ab}$ & 0 \\
$\begin{array}{l}\text { Larvae with gut } \\
\text { removed }\end{array}$ & $83.8 \mathrm{ab}$ & $0.8 \mathrm{~b}$ & 3.3 \\
\hline
\end{tabular}

\footnotetext{
$\dagger$ Means are back-transformed from the log scale. $\ddagger$ Means within a column having the same letter are not significantly different at $P=0.05$.
}

A standard curve was determined using the above method with three known concentrations of OTC between $0-0.1 \mathrm{mg} / \mathrm{kg}$, which was replicated three times. The diameters of the zones of inhibition were measured and the means calculated and converted to $\mathrm{mg} / \mathrm{kg}$ to form a standard curve (Fig. 1).

For HPLC, $20 \mu \mathrm{L}$ of $75 \% \mathrm{w} / \mathrm{v}$ trichloroacetic acid was added to the remainder of the solution prepared for MIT and blended for 10 seconds. This was then centrifuged at $4000 \mathrm{rpm}$ and $4{ }^{\circ} \mathrm{C}$ for 10 minutes. The clear supernatant was poured into a $3 \mathrm{~mL}$ syringe and filtered though a 0.45 micron filter for HPLC analysis. HPLC was conducted using a Waters 2690 separation module and 996 Photo Diode Array (Waters Australia). The analytical column used was a Zorbax C-8 XDB, $150 \times 4.6 \mathrm{~mm}$, particle size 5 micron, with an equivalent $\mathrm{C}-8$ guard column. The mobile phase comprised $0.1 \%$ trifluoroacteic acid, $85 \%$ MilliQ water and $14.9 \%$ acetonitrile. Flow rate was $1 \mathrm{~mL}$ per minute. Duplicate analysis was conducted in every 10th sample with \% RSD's less than $8 \%$. Spiked control values were in the range of 75$110 \%$. Data was collected between $300 \mathrm{~nm}$ and
$400 \mathrm{~nm}$ and the concentration of OTC was calculated at $357.3 \mathrm{~nm}$, the wavelength maximum of OTC.

\section{RESULTS}

\subsection{Pre-treatment samples}

OTC activity was not detected in any pretreatment samples taken for all experiments.

\subsection{Experiment 1.Concentration of OTC in whole larvae and larval guts}

The mean concentration of OTC in the treatments averaged across both hives used in the experiment is presented in Table II. On day 1 , whole larvae had over twice the OTC concentration of larval guts, this difference being significant at $P<0.05$. Larvae with guts removed also had a higher concentration than larval guts, though the difference was not significant at $P=0.05$. On day 3 , OTC was detected in only one of the two hives in whole larvae and larval guts (i.e. in only half the samples), and in only one sample out of 10 in larvae with guts removed. On day 6, only 4 samples out of 30 had detectable OTC (all in larvae with guts removed). The mean OTC concentrations on days 3 and 6 were therefore very low.

There was very little association $(r=-0.07)$ between the concentration of OTC in larval guts and larvae with guts removed, even though they arose from the same larvae. The 
Table III. Mean concentration of OTC in larvae for each treatment group over six days from medication (Experiments 2 and 3).

\begin{tabular}{lccccccc}
\hline & \multicolumn{6}{c}{ OTC concentration $(\mathrm{mg} / \mathrm{kg})$ for each treatment and size of colony } \\
Days post medication & $0.3 \mathrm{~g}$ OTC & $0.5 \mathrm{~g}$ OTC & $1.0 \mathrm{~g}$ OTC & approx. 1.s.r. \\
& $(1)^{*}$ & $(2)^{*}$ & $(1)$ & $(2)$ & $(1)$ & $(2)$ & \\
\hline 1 & 12.6 & 8.2 & 25.1 & 10.5 & 41.9 & 29.0 & 1.5 \\
2 & 6.1 & 3.0 & 7.6 & 6.4 & 19.2 & 11.1 & 1.6 \\
3 & 1.2 & 1.0 & 2.2 & 1.4 & 12.3 & 5.1 & 1.8 \\
4 & 1.6 & 0.3 & 1.7 & 1.0 & 11.3 & 2.7 & 1.7 \\
5 & 1.0 & 0.2 & 1.6 & 0.5 & 2.6 & 1.2 & 2.0 \\
6 & 0.2 & 0 & 1.0 & 0.3 & 3.8 & 0.8 & 2.1 \\
\hline
\end{tabular}

*Denotes size of colony in storeys.

other associations (whole larvae and larval guts; whole larvae and larvae with guts removed) were stronger, but were heavily influenced in each case by one observation, and were not significant at $P=0.05$.

\subsection{Experiments 2 and 3. Concentration of OTC in larvae following summer and spring application of the antibiotic in caster sugar}

\subsubsection{Effect of OTC treatment on honey bee colonies}

In both experiments, death of larvae and cessation of egg-laying occurred in one of the single storey hives treated with $1 \mathrm{~g}$ OTC. In Experiment 3, some sick and dead brood were evident in one single storey hive treated with $0.5 \mathrm{~g}$ OTC and two hives treated with $1.0 \mathrm{~g}$ OTC.

\subsubsection{Weather}

On the first day after treatment in Experiment 1, some bee flight was possible although approximately $40 \mathrm{~mm}$ of rain fell and the maximum temperature was $22.5^{\circ} \mathrm{C}$. During Experiment 2, weather on the first 6 days after treatment was suitable for bee foraging although day 4 was hot and windy; rain fell on day 7. For Experiment 3, bees foraged during warm and windy conditions that occurred immediately prior to and during treatment of the hives. Shortly after treatment, an approaching cold front caused rapid deterioration of the weather and very little foraging was possible for the next 72 hours.

\subsubsection{Clean-up of OTC treatments in hives}

On post-treatment day 1 in Experiment 2, two single storey hives treated with $1 \mathrm{~g}$ OTC and a double storey hive treated with $0.5 \mathrm{~g}$ OTC had not removed medication from the top bars of frames and in some cases had medication in open brood cells; samples were not taken from these hives. On post-treatment day 1 in Experiment 3, all single storey hives treated with $1 \mathrm{~g}$ OTC, a double storey hive treated with $0.5 \mathrm{~g}$ OTC and a double storey hive treated with $1.0 \mathrm{~g}$ OTC had not removed medication from all of the top bars of frames. It is possible that more hives could have been included in this category had weather not prevented inspection of every hive.

\subsubsection{Concentration of OTC}

Table III gives the mean concentration of OTC in larvae for each treatment group for six days immediately following medication of the hives. On day 1 , the mean concentration of OTC in larvae sampled from $0.5 \mathrm{~g}$ OTC single-storey hives was significantly greater $(P<0.05)$ than that in $0.3 \mathrm{~g}$ OTC single-storey hives. The same trend continued after day 1 , but the differences were not significant at $P=0.05$. On each of the six days, mean concentrations of OTC were significantly greater $(P<0.05)$ for the $1.0 \mathrm{~g}$ OTC doublestorey hive treatments than for the $0.5 \mathrm{~g}$ OTC double-storey hive treatments, usually by a factor of 2-3.

Table IV shows the mean rate of change of OTC concentration per day for each treatment 
Table IV. Mean rate of change of OTC concentration in larvae for each treatment group in Experiments 2 and 3 .

\begin{tabular}{lcccc}
\hline Experiment & $\begin{array}{c}\text { OTC Dose } \\
\text { (g active })\end{array}$ & \multicolumn{2}{c}{ Mean rate of change of OTC in larvae } & $\begin{array}{c}\text { approx. } \\
\text { 1.s.r. }\end{array}$ \\
& & Single-storey hive & Double-storey hive & \\
\hline $\begin{array}{l}\text { Experiment 2 } \\
\text { (Summer) }\end{array}$ & 0.3 & 0.512 & 0.423 & \\
& 0.5 & 0.587 & 0.470 & 1.3 \\
& 1.0 & 0.672 & 0.527 & \\
Experiment 3 & 0.3 & 0.554 & 0.563 & 1.3 \\
(Spring) & 0.5 & 0.543 & 0.578 & \\
& 1.0 & 0.471 & 0.425 & \\
\hline
\end{tabular}

Table V. Estimated level of OTC at the time of treatment (day $=0)$ for each treatment group in Experiments 2 and 3.

\begin{tabular}{lcccc}
\hline Experiment & $\begin{array}{c}\text { OTC dose } \\
\text { (g active })\end{array}$ & \multicolumn{2}{c}{$\begin{array}{c}\text { Level of OTC at time of treatment } \\
(\mathrm{mg} / \mathrm{kg})\end{array}$} & $\begin{array}{c}\text { approx. } \\
\text { 1.s.r. }\end{array}$ \\
& & Single-storey hive & Double-storey hive & \\
\hline $\begin{array}{l}\text { Experiment 2 } \\
\text { (Summer) }\end{array}$ & 0.3 & 26.4 & 19.9 & \\
& 0.5 & 23.4 & 25.1 & 2.6 \\
& 1.0 & 40.7 & 41.9 & \\
Experiment 3 & 0.3 & 13.3 & 8.0 & 2.9 \\
(Spring) & 0.5 & 28.6 & 13.7 & \\
& 1.0 & 172.2 & 104.4 & \\
\hline
\end{tabular}

group. These means are presented for the two experiments separately because the ANOVA showed that there was a significant treatment group by experiment interaction. An example of the meaning of these figures is that for Experiment 2, for single-storey hives given a dose of $0.3 \mathrm{~g}$ OTC, the rate of change of OTC concentration per day is estimated to be 0.512 , i.e. the concentration approximately halves each day after treatment. The only significant difference of note occurred between $0.5 \mathrm{~g}$ and $1.0 \mathrm{~g}$ OTC double-storey hives in spring (Experiment 3).

Table V shows the estimated level of OTC in larvae immediately after treatment using the mean intercept at day 0 (i.e. time of medication) from the regressions of the logarithm of OTC concentration against the number of days. The only significant difference of note occurred between $0.5 \mathrm{~g}$ and $1.0 \mathrm{~g}$ OTC doublestorey hives in spring (Experiment 3 ).

In addition to the above, we combined the results of Tables IV and V and concluded that: (i) there was not much evidence of a clear difference between $0.5 \mathrm{~g}$ and $0.3 \mathrm{~g}$ OTC single-storey hives in terms of how OTC concentration changed over time following treatment; (ii) there was some evidence of a difference between $0.5 \mathrm{~g}$ and $1.0 \mathrm{~g}$ OTC double-storey hives. In summer, OTC concentration started at a lower level for the $0.5 \mathrm{~g}$ treatment and decreased at a faster rate, though neither the starting levels nor the rates were significantly different. In spring, OTC concentration started at a much lower level for the $0.5 \mathrm{~g}$ treatment, but it decreased at a slower rate.

In summer, OTC continued to be detected on day 10 , (post treatment) in one $1.0 \mathrm{~g}$ OTC 
single storey-colonies (mean 11.85; range 1.2$43.0 \mathrm{mg} / \mathrm{kg}$ ) and two $1.0 \mathrm{~g}$ OTC double-storey colonies (mean 1.0; range $0.8-1.2 \mathrm{mg} / \mathrm{kg}$ ). Similarly, in spring (Experiment 3), OTC was detected on day 11 (post treatment) in three $1.0 \mathrm{~g}$ OTC single-storey colonies (mean 0.93; range $0.8-1.2 \mathrm{mg} / \mathrm{kg}$ ) and one $1.0 \mathrm{~g}$ OTC double-storey colony $(0.8 \mathrm{mg} / \mathrm{kg})$.

\subsection{Experiment 4. Concentration of OTC in larvae following spring application of the antibiotic in water}

The $0.3 \mathrm{~g}$ and $0.5 \mathrm{~g}$ OTC treatments dissolved in $200 \mathrm{~mL}$ of distilled water contained $1.46 \%$ and $2.45 \%$ sugar respectively. Although the mean level of OTC in larvae was generally higher for the $0.5 \mathrm{~g}$ treatment, the difference was not significant (at $P<0.05$ ) on any day (Tab. VI). The estimated rates of change of OTC concentration per day for the $0.3 \mathrm{~g}$ and $0.5 \mathrm{~g}$ OTC treatments were 0.186 and 0.275 respectively, but these were not significantly different (approximate 1.s.r. $=2.3$ ). The estimated levels of OTC immediately after treatment (day $=0$ ) were 55.7 and 38.5 respectively, which were again not significant (approximate 1.s.r. $=10.1$ ).

Table VI. Mean concentration of OTC in larvae for each water treatment for three days from medication (Experiment 4).

\begin{tabular}{lccc}
\hline $\begin{array}{l}\text { Days post } \\
\text { medication }\end{array}$ & \multicolumn{2}{c}{$\begin{array}{c}\text { Concentration of OTC } \\
\text { in larvae }(\mathrm{mg} / \mathrm{kg})\end{array}$} & $\begin{array}{c}\text { 1.s.d. } \\
\text { 0.3 g }\end{array}$ \\
& $\begin{array}{c}0.5 \mathrm{~g} \\
\text { OTC/hive }\end{array}$ & \\
& OTC/hive & \\
\hline 1 & 11.0 & 11.3 & 9.0 \\
2 & 4.3 & 6.4 & 2.4 \\
3 & 0.24 & 0.48 & 0.41 \\
\hline
\end{tabular}

\section{DISCUSSION}

This work expands on that of Hornitzky et al. (1988), and developed a successful HPLC method for the detection of OTC in honey bee larvae. However, this method proved only advantageous over conventional MIT screens in determining an accurate OTC concentration in larvae when at high levels.
M. pluton multiplies within the mid-gut of the honey bee larva (Bailey and Ball, 1991). Assay of the gut and its contents for OTC would provide meaningful data to determine if a particular dose provided sufficient antibiotic to meet the MIC for M. pluton at the site where the bacterium multiplies. However, accurate dissection of larvae to remove the gut (Experiment 1) was difficult, and some contamination between gut, haemolymph and larval tissue may have occurred. Consequently, we suggest that dissection of larvae is not practical as a routine technique and assay of whole larvae is the only practical means to conduct this type of experiment.

The high concentration of OTC in whole larvae sampled on post treatment day 1 in Experiment 1 (Tab. II), may have been caused by medication adhering to the external surface of larvae. However, similar levels of OTC were not detected in Experiments 2 and 3 when identical treatment was applied to two-storey colonies. Absorption of OTC from the gut to body tissue may have also occurred. By day 3, the amount of OTC in whole larvae was much reduced possibly as a consequence of metabolism and degradation. Unfortunately, statistical analysis demonstrated little association between "treatments" and development of an equation to predict OTC levels in the midgut was not pursued. However, the data obtained in Experiment 1 strongly indicate a lower concentration of OTC in the gut as opposed to whole larvae (Tab. II).

Detection of OTC in larvae sampled eleven and ten days post-treatment (Experiments 2 and 3 respectively), from single and doublestorey colonies treated with $1.0 \mathrm{~g}$ OTC, indicated a longer period of OTC activity than that of up to nine days demonstrated by Hornitzky et al. (1988). On the third day following treatment, only single storey colonies treated with either $0.5 \mathrm{~g}$ or $1.0 \mathrm{~g}$ OTC, and double storey colonies treated with $1.0 \mathrm{~g}$ OTC had mean concentrations of OTC above the $2 \mu \mathrm{g} / \mathrm{mL}$ MIC for M. pluton (Hornitzky and Smith, 1999). On day four, only $1.0 \mathrm{~g}$ OTC single and double storey colonies met the MIC. These results illustrate a very quick degradation or metabolism of OTC in larvae following medication. Thus the bacteriostatic action of OTC only inhibits $M$. pluton growth 
in the larval gut for a short period and for only one generation of larvae.

The only noteworthy rate of change of OTC concentrations in larvae over time in Experiments 2 and 3 that was significantly different was between the $0.5 \mathrm{~g}$ and $1.0 \mathrm{~g}$ OTC doses given to double-storey colonies in spring. Otherwise, the rate of change in OTC over time appeared to have no consistent relationship with the dose administered (Tab. IV), with the mean rate of change for all treatments for both experiments being $0.527 \mathrm{mg} / \mathrm{kg}$ for each day of treatment. The estimated level of OTC at the time of treatment $($ day $=0)$ increased with the initial OTC dose (Tab. V) in all cases except for the $0.3 \mathrm{~g}$ and $0.5 \mathrm{~g}$ OTC single-storey doses of Experiment 2, where the level was similar. This result was unexpected and was not repeated in the replicate trial of Experiment 3.

The inclusion of the water treatment, (Experiment 4, Tab. VI) was requested by some Australian apiarists who had been trialing this treatment. Both $0.3 \mathrm{~g}$ and $0.5 \mathrm{~g}$ OTC water applications delivered antibiotic above the MIC for M. pluton for 2 days (Tab. VI). These treatments also gave higher estimated levels of OTC at the time of treatment $($ day $=0)$ and equal or higher OTC levels on the first two days post-treatment when compared with the same doses applied in caster sugar to two-storey colonies. However, by day 3 the concentration of OTC in larvae treated with OTC in water was considerably lower than that in larvae fed with medicated caster sugar. We suggest that this may be the result of increased degradation or metabolism of the antibiotic, or the leaking of the medication out of the hive, however this was not observed.

Medication of single-storey colonies with $1 \mathrm{~g} \mathrm{OTC}$ is not normal industry practice and this treatment was included in these experiments to obtain information only. In Experiments 2 and 3, a reluctance by bees to quickly 'clean-up' this treatment, plus mortality of larvae and cessation of or reduced egg-laying by the queen demonstrated the effects of over dosing.

In human and veterinary medicine, medicinal doses are given to ensure a concentration in the blood of 4 or even 8 times higher than the MIC for a specific medication and organism. The amount for which the level of OTC in honey bee larvae should exceed the MIC of $1-2 \mu \mathrm{g} / \mathrm{mL}$ established by Hornitzky and Smith (1999) is not known. Our results, based on whole larval assays, show that all treatments in Experiments 2, 3 and 4 delivered sufficient antibiotic to exceed the MIC by a minimum of 4 times on day 1 after treatment and a minimum of about 10 times at the time of treatment (day $=0$ ). However, we suggest some caution in interpreting this data on the basis that Experiment 1 indicated a lower concentration of OTC in the gut compared to whole larvae (Tab. II). The $1 \mathrm{~g}$ dose of OTC for double storey colonies is effective in controlling EFB in Australia, and on that basis must provide sufficient antibiotic to meet or exceed the MIC. The ability of $0.5 \mathrm{~g}$ and $0.3 \mathrm{~g}$ doses to deliver sufficient OTC to the larval gut (the site where $M$. pluton develops) to meet the MIC has not been shown by this work. We suggest that until the efficacy of these doses for control of EFB can be demonstrated by field trials doses should not be reduced. In addition, any reduction in OTC may also encourage $M$. pluton to develop resistance to the antibiotic. The current $0.5 \mathrm{~g}$ and $1.0 \mathrm{~g}$ doses administered to single-storey and double-storey colonies respectively are therefore appropriate for control of EFB in Australia.

\section{ACKNOWLEDGEMENTS}

We thank Dr. Michael Hornitzky, Elizabeth MacArthur Agriculture Institute, NSW Agriculture, Camden, NSW and Dr Peter Taylor, The University of Melbourne, Parkville, Victoria, for helpful advice and encouragement. This project was funded in part by a grant from the Rural Industries Research and Development Corporation.

Résumé - Activité de l'hydrochlorure d'oxytetracycline chez les larves d'abeilles domestiques (Apis mellifera) après médication à diverses doses. La loque européenne (EFB) est une maladie des larves d'abeilles (Apis mellifera L.) causée par la bactérie Melissococcus pluton (Bailey, 1957). La maladie provoque des pertes importantes de couvain, une diminution de la production de miel et peut, dans les cas sévères, entraîner la mort de la colonie (Goodman et al., 1994). On utilise l'antibiotique hydrochlorure d'oxytetracycline (OTC) pour traiter la maladie et son efficacité a été largement démontrée (Katznelson et al., 1952 ; Lehnert et Shimanuki, 
1980 ; Hornitzky et al., 1988). L'OTC est utilisé dans de nombreux pays et administré aux ruches dans du sucre en poudre, du sirop de sucre ou des pâtés à action prolongée (Gilliam et Argauer, 1981). On a réalisé quatre expériences pour déterminer la concentration des larves en OTC suite à une médication utilisant diverses préparations. Dans la première expérience on a déterminé les concentrations en OTC dans les larves entières, les tubes digestifs et les larves sans tube digestif. Les concentrations en OTC dans les larves entières étaient significativement plus élevées que dans les tubes digestifs seuls le jour suivant le traitement; cela peut être dû au fait que l'OTC adhère à l'extérieur de la larve et aux cellules du rayon et à l'absorption de l'OTC consommé du tube digestif vers le tissu cellulaire. Dans deux expériences répétées, on a appliqué $0,3 \mathrm{~g}, 0,5 \mathrm{~g}$ et $1,0 \mathrm{~g}$ d'OTC mélangé à du sucre en poudre à des colonies à une et deux hausses. Les concentrations moyennes en OTC dans les larves entières étaient au-dessus de la concentration inhibitrice minimum (MIC) pour $M$. pluton de 1-2 $\mu \mathrm{g} / \mathrm{mL}$ (Hornitzky et Smith, 1999) dans la période de 2 à 6 jours après le traitement. Durant 11 jours maximum suivant le traitement l'OTC a pu être détecté dans les larves et le taux journalier de décroissance de l'OTC dans les larves provenant des colonies traitées a varié entre 0,423 et 0,672 . Des doses de 0,3 et $0,5 \mathrm{~g}$ d'OTC administrées à des ruches dans de l'eau distillée ont donné des concentrations larvaires en OTC égales ou supérieures à celles obtenues par l'administration avec le sucre en poudre.

Les données établies par ces expériences confirment l'efficacité des dosages actuellement utilisés $(0,5 \mathrm{~g}$ pour une colonie à une hausse, $1,0 \mathrm{~g}$ pour une colonie à deux hausses) dans le traitement de la loque européenne en Australie. Toute réduction des doses d'OTC pourrait favoriser l'apparition de résistance chez M. pluton.

loque européenne / antibiotique / hydrochlure d'oxytétracycline / Australie

\footnotetext{
Zusammenfassung - Aktivität von Oxytetracyclinhydrochlorid in Honigbienenlarven (Apis mellifera) nach einer Medikamentierung mit verschiedenen Dosierungen. Die Europäische Faulbrut (EHB) ist eine durch das Bakterium Melissococcus pluton (Bailey, 1957) verursachte Krankheit der Honigbienenlarven (Apis mellifera L.). Die Krankheit verursacht starke Brutverluste, verminderte Honigproduktion, und kann in schweren Fällen zum Verlust der Kolonie führen (Goodman et al., 1994). Das Antibiotikum Oxytetracyclinhydrochlorid (OTC) wird zur Behandlung der EFB eingesetzt, ihre Wirksamkeit wurde wiederholt demonstriert (Katznelson et al., 1952; Lehnert and Shimanuki, 1980; Hornitzky et al., 1988). OTC wird in vielen Ländern eingesetzt und wird zumeist in Feinzucker, Zuckersyrup oder
}

Öl-Zuckerteigplätzchen (“extender patties”) zur Anwendung gebracht (Gilliam and Argauer, 1981). In der vorliegenden Studie wurden vier Experimente zur Bestimmung der Konzentration von OTC in Larven nach einer Behandlung mit verschiedenen Anwendungen durchgeführt. In dem ersten Experiment wurden OTC Konzentrationen in ganzen Larven, in Larvenverdauungstrakten und in Larven mit entfernten Verdauungstrakten bestimmt. Die Konzentrationen von OTC waren an dem Tag nach der Behandlung in den ganzen Larven erheblich höher als in den Verdauungstrakten. Dies ist möglicherweise auf äußerlich an der Larve und der Wabenzelle anhaftendes OTC sowie auf die Absorption aufgenommenen OTCs vom Darm in das Körpergewebe zurückzuführen. In zwei wiederholten Experimenten wurden ein - und zweizargige Völker mit $0,3 \mathrm{~g}, 0,5 \mathrm{~g}$ und 1,0 g OTC in Feinzucker behandelt. Die mittleren OTC Konzentrationen in ganzen Larven waren oberhalb der minimalen Hemmkonzentration (MIC) für $M$. pluton von 1-2 $\mu \mathrm{g} / \mathrm{mL}$ im Zeitintervall 2-6 Tage nach der Behandlung (Hornitzky and Smith, 1999). OTC konnte bis mindestens 11 Tage nach der Behandlung in den Larven nachgewiesen werden, die tägliche Abnahmerate lag bei 0,423 bis 0,672 . Dosierungen von $0,3 \mathrm{~g}$ und $0,5 \mathrm{~g}$ in destilliertem Wasser auf Völker angewendeten OTC führten zu gleichen oder höheren Konzentrationen von OTC in den Larven nach der Behandlung wie die Anwendung in Feinzucker.

Die durch das Experiment erhaltenen Daten bestätigen die Wirksamkeit der derzeitig verwendeten Dosierungen $(0,5 \mathrm{~g}$ OTC in einzargigen Magazinen, 1,0 g OTC in zweizargigen Magazinen) zur Behandlung von EFB in Australien. Verminderung der Dosierungen von OTC könnte die Entwicklung von Resistenz von $M$. pluton gegen OTC begünstigen.

\section{Oxytetracyclinhydrochlorid / Antibiotika / Honigbienen / Europäische Faulbrut / Australien}

\section{REFERENCES}

Bailey L. (1957) The isolation and cultural characteristics of Streptococcus pluton and further observations on Bacterium eurydice, J. Gen. Microbiol. 31, 147-150.

Bailey L., Ball B.V. (1991) Honey bee pathology (2nd ed.), Academic Press, London.

Dade H.A. (1962) Anatomy and dissection of the honeybee, Bee Research Association, London.

Gilliam M., Argauer R.J. (1981) Terramycin residues in surplus and brood nest honey after medication of honeybee colonies by three different methods (1), Gleanings in Bee Cult. 109, 545-551. 
Goodman R.D., Azuolas J.K., Hepworth G., McMonigle J., Kaczynski P., Hunt P.J. (1994) Oxytetracycline hydrochloride in Australian honey and the storage of oxytetracycline hydrochloride in beehives, Research report to Honeybee Research and Development Council (Australia).

Hornitzky M.A.Z., Karlovskis S., Hallstrom A.L. (1988) Oxytetracycline activity in honeybee larvae following hive treatment with various oxytetracycline preparations, J. Apic. Res. 27, 293-244.

Hornitzky M.A.Z., Smith L.A. (1999) Sensitivity of Australian Melissococcus pluton isolates to oxytetracycline hydrochloride, Aust. J. Exp. Agric. 39, 881-883.
Katznelson H., Arnott, J.A., Bland S.E. (1952) Preliminary report on the treatment of European foulbrood of honey bees with antibiotics, Sci. Agric. 32, 180-184.

Lehnert T., Shimanuki H. (1980) European foulbrood control in honey bee colonies used for blueberry and cranberry pollination, Am. Bee J. 120, 429430.

Lehnert T., Shimanuki H. (1981) Oxytetracycline residues in honey following three different methods of administering the antibiotic, Apidologie, 12, 133-136.

Matsuka M., Nakamura J. (1990) Oxytetracycline residues in honey and royal jelly, J. Apic. Res. 29, 112-117. 